\section{Anatomical Aspects of K, Mn, and Fe Deficiencies in Queen Palm}

\author{
Alan W. Meerow and Timothy K. Broschat \\ Research and Education Center, University of Florida, 3205 College \\ Avenue, Fort Lauderdale, FL 33314
}

Additional index words. nutrition, histology, Syagrus romanzoffiana

Abstract. Anatomical differences in leaves of queen palm [Syagrus romanzoffiana (Chamisso) Glassman] showing visible $\mathrm{K}$, Mn, and Fe deficiency symptoms are described. Potassium-deficient leaves showed less organization in the mesophyll than healthy leaves. Adaxial fibers increased in diameter. Chloroplast frequency was reduced overall, but most severely in areas of the leaf showing gross symptoms of the deficiency. Manganese-deficient leaves had reduced chloroplast frequency, especially in tissue near necrotic areas, and thicker and more fibers per unit length. Iron-deficient leaves had few chloroplasts throughout the mesophyll, and also thicker and more fibers per unit length.

Deficiencies of $\mathrm{K}, \mathrm{Mn}, \mathrm{Fe}$, and $\mathrm{Mg}$ are very common on palms in many parts of the world. The queen palm is widely grown in warmer regions of the United States for its attractive form, moderate size, and cold tolerance. It is extremely prone to $\mathrm{K}$ and $\mathrm{Mn}$ deficiencies on alkaline and highly leached sandy soils (Chase and Broschat, 1991; Dickey, 1977) and often exhibits Fe deficiency symptoms when grown in poorly aerated soils or when transplanted too deeply (Broschat and Donselman, 1985; Chase and Broschat, 1991).

Potassium deficiency symptoms occur first on oldest leaves as small (1 to $2 \mathrm{~mm}$ ), translucent, yellow-orange spots on the leaflets. As the deficiency progresses, newer leaves exhibit spotting, whereas marginal necrosis appears on leaflets of older leaves. In more severe cases, older leaves are entirely necrotic or frizzled in appearance and most younger leaves are chlorotic with extensive marginal necrosis. Eventually the trunk tapers to a point and the bud dies (Broschat, 1990; Chase and Broschat, 1991).

Manganese deficiency symptoms occur only on new leaves that emerge reduced in size, chlorotic, and have extensive necrotic streak-

Received for publication 3 Aug. 1990. Florida Agricultural Experiment Stations Journal Series no. R-00533. The cost of publishing this paper was defrayed in part by the payment of page charges. Under postal regulations, this paper therefore must be hereby marked advertisement solely to indicate this fact. ing. Succeeding leaves will be extremely small and completely necrotic (the condition is termed "frizzletop" by nursery and landscape horticulturists). In later stages, only necrotic petiole stubs will emerge, and death of the bud will quickly follow (Chase and Broschat, 1991). Late-stage $\mathrm{K}$ deficiency and early stage $\mathrm{Mn}$ deficiency are virtually indistinguishable from a distance and misdiagnosis is common.

Early symptoms of Fe deficiency include queen palm leaves.

${ }^{2}+$, areas with symptoms; -, areas without symptoms. different leaves. leaves. a general chlorosis of the newest leaves with small (2 to $4 \mathrm{~mm}$ ) green spots scattered throughout otherwise yellowish leaves. Under more severe Fe deficiency conditions, the leaves are entirely yellow, with extensive leaflet necrosis and reduced leaf size (Chase and Broschat, 1991). Superficially, Fe deficiency symptoms are similar to those of midstage K deficiency or early stage Mn deficiency.

There is relatively little literature documenting anatomical changes in tissues of ornamental plants associated with specific nutritional deficiencies, and no reports relating to palms were found. Struckmeyer and her students studied the anatomical effects of $\mathrm{N}, \mathrm{P}, \mathrm{K}, \mathrm{Ca}, \mathrm{Mg}, \mathrm{B}, \mathrm{S}$, and $\mathrm{Zn}$ deficiencies on poinsettia (Struckmeyer, 1960); Mg, $\mathrm{Ca}$, and $\mathrm{B}$ deficiency on geranium (Struckmeyer, 1968) and daminozide on B-deficient marigold (McConnell and Struckmeyer, 1972). Bussler (1981) described some effects of Fe deficiency on leaf or root anatomy of sunflower, coleus, and cauliflower.

Since visual symptoms for K, $\mathrm{Mn}$, and $\mathrm{Fe}$ deficiencies in queen palm overlap considerably, it would be useful to determine how these deficiencies differ in their effect on leaflet anatomy and to see if these differences can be used in diagnosing these deficiencies. Although visual deficiency symptomology has been described for many

Table 1. Chloroplast frequency and adaxial fiber size and frequency of healthy and nutrient deficient

\begin{tabular}{|c|c|c|c|c|}
\hline \multirow[b]{2}{*}{ Treatment } & \multirow[b]{2}{*}{ Symptoms $^{2}$} & \multirow[b]{2}{*}{ Chloroplast frequency } & \multicolumn{2}{|c|}{ Adaxial fibers } \\
\hline & & & Frequency $^{x}$ & $\begin{array}{c}\text { Diam }^{w} \\
(\mu \mathrm{m})\end{array}$ \\
\hline No deficiency & & $6.8 \pm 1.2$ & $1.2 \pm 0.6$ & $15.0 \pm 4.0$ \\
\hline Early K deficiency & & & $1.5 \pm 0.4$ & $16.0 \pm 5.0$ \\
\hline & + & $\begin{array}{l}2.1 \pm 0.7 \\
4.9 \pm 0.8\end{array}$ & & \\
\hline Moderate K deficiency & & & $1.4 \pm 0.5$ & $38.0 \pm 6.0$ \\
\hline & + & $\begin{array}{l}2.2 \pm 0.7 \\
3.8 \pm 0.8\end{array}$ & & \\
\hline Severe K deficiency & & & $1.2 \pm 0.3$ & $36.0 \pm 5.0$ \\
\hline & \pm & $\begin{array}{l}2.0 \pm 0.8 \\
3.6 \pm 0.7\end{array}$ & & \\
\hline Mn deficiency & & & $3.3 \pm 0.4$ & $34.0 \pm 7.0$ \\
\hline & + & $\begin{array}{l}1.8 \pm 0.7 \\
3.3 \pm 0.5\end{array}$ & & \\
\hline Early Fe deficiency & + & $1.1 \pm 0.6$ & $3.8 \pm 0.5$ & $41.0 \pm 8.0$ \\
\hline Severe Fe deficiency & + & $1.0 \pm 0.2$ & $3.6 \pm 0.6$ & $43.0 \pm 6.0$ \\
\hline
\end{tabular}

${ }^{y}$ Chloroplasts per mesophyll cell; mean \pm SD of 30 cells per section from three sections each of two

${ }^{x}$ Fibers per $250 \mu \mathrm{m}$ section length; mean \pm SD of 10 sections each of two different leaves.

"Mean \pm SD of widest diameter of 20 fibers per section from three sections each of two different 


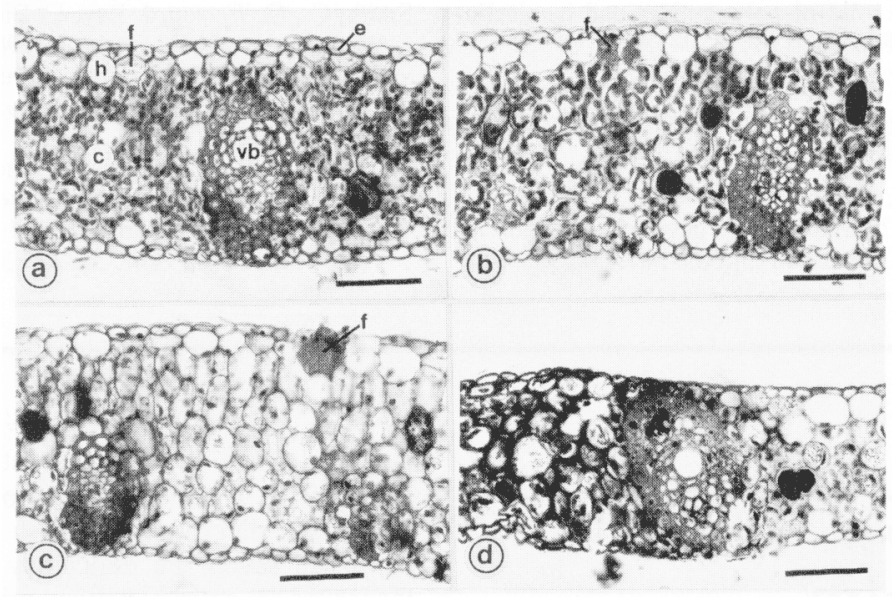

Fig. 1. Transverse section through healthy and K-deficient queen palm leaves. (a) Healthy. (b) Early stages of $\mathrm{K}$ deficiency (isolated orange flecking); note slight reduction in chloroplast frequency compared with (a) and conspicuous adaxial fibers. (c) Middle stages of $\mathrm{K}$ deficiency (extensive orange flecking); note marked decrease in chloroplast frequency and further increase in adaxial fiber diameter. (d) Late stages of $\mathrm{K}$ deficiency (marginal necrosis). $\mathrm{e}=$ epidermis, $\mathrm{h}=$ hypodermis, $\mathrm{c}$ $=$ chlorenchyma, $\mathrm{f}=$ fiber, $\mathrm{vb}=$ vascular bundle. Adaxial surface at top of figures. All scales = $50 \mu \mathrm{m}$.

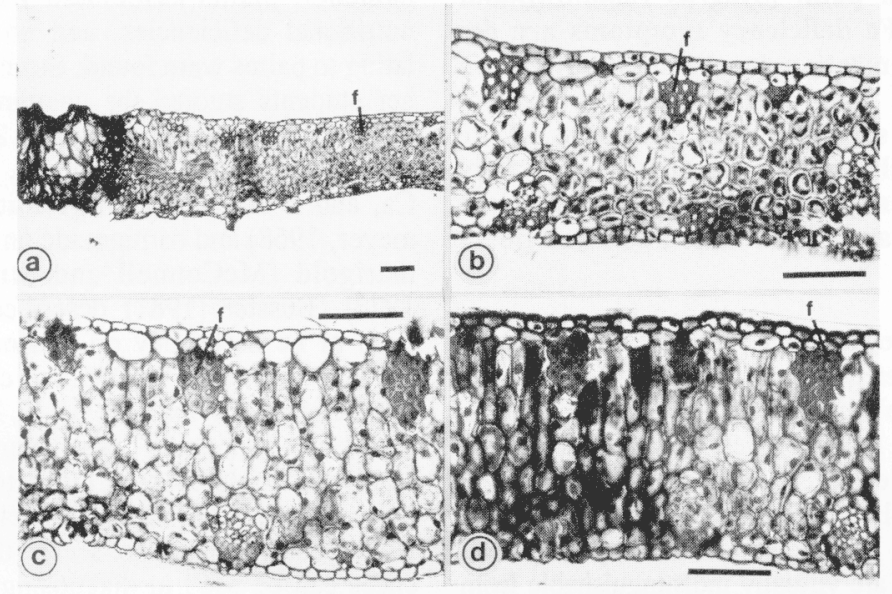

Fig. 2. Transverse section through $\mathrm{Mn}$ - and Fe-deficient queen palm leaves. (a-b) Mn deficiency. (a) Transition from non-necrotic to necrotic tissue. Note increased diameter and frequency of adaxial fibers. (b) Non-necrotic area. (c-d) Fe deficiency. (c) Early stages of Fe deficiency (green spotting). Note large diameter and high frequency of adaxial fibers. (d) Later stages of Fe deficiency (necrotic spot stage). $\mathrm{f}=$ fiber. Adaxial surface at top of figures. All scales $=50 \mu \mathrm{m}$.

species of palms (Broeshart et al., 1957; Broschat, 1984; Bull, 1961a, 1961b; Manciot et al., .1979, 1980), this is, to our knowledge, the first study of anatomical aspects of nutritional deficiencies in the family.

Leaf samples for anatomical studies were obtained from 3-year-old queen palms grown under shadecloth (maximum of 800 $\left.\mu \mathrm{mol} \cdot \mathrm{s}^{-1} \cdot \mathrm{m}^{-2}\right)$. Palms were grown in 10 liter plastic containers filled with media known to induce deficiencies of certain elements (Broschat and Donselman, 1985). Severe Mn deficiency was induced by growing palms in a composted sewage sludge medium from Ft. Lauderdale, Fla. Severe Fe deficiency was induced by growing in a composted urban yard waste (tree trimmings) medium low in Fe. Mild $\mathrm{K}$ deficiency symptoms were induced in a 4 pine bark : 2 sedge peat : 1 sand (by volume) medium in which the plants received insufficient $\mathrm{K}$ fertilizer. All syrnp- toms were typical of those documented by Chase and Broschat (1991) for that species and were confirmed by leaf nutrient analysis.

One symptomatic leaf each was sampled from two plants within each treatment. Two leaflets from each leaf were removed from the midpoint of the rachis, cut into $20-$ to $25-\mathrm{mm}^{2}$ sections, fried in FAA, transferred to $50 \%$ ethanol $(\mathrm{EtOH})$, dehydrated in graded $\mathrm{EtOH}$ and tert-butyl alcohol series, infiltrated with Hemo-D, and embedded in paraffin (Sass, 1958). Transverse sections $12 \mu \mathrm{m}$ thick were prepared and stained with safranin and fast green (Sass, 1958). All measurements (Table 1) were made using camera lucida and a calibrated ocular micrometer.

Tomlinson (1961) characterized the leaf anatomy of S. romanzoffiana as dorsiventral, with a mostly single-layer hypodermic, a distinct adaxial palisade layer (not well-developed in our shade-grown material), and abundant, undignified fibers (Fig. la). In the early stages of $\mathrm{K}$ deficiency (isolated orange flecking symptomology), the mesophyll became less organized, with the palisade cells less distinguishable than in healthy tissue (Fig. lb). Similar observations were reported by Struckmeyer (1960) in K-deficient poinsettia. Cell elongation is known to depend on K concentration (Haschke and Lüttge, 1975), which may explain changes in cell shape. Chloroplast frequency within the leaf chlorenchyma decreased overall, but not uniformly (Table 1). Regions of the mesophyll with fewer chloroplasts were always subjacent to areas of the epidermis exhibiting the orange, translucent spots. Intervenal areas of the mesophyll did not show as much reduced chloroplast frequency (Fig. lb). No thickening of the lamina was observed, unlike that reported for cauliflower (Singh and Sharma, 1988). Leaves exhibiting extensive orange flecking showed a further slight decrease in chloroplast frequency in cells not immediately underlying symptomatic areas (Table 1), but again, more extensive chloroplast reduction was in mesophyll cells underlying the- flecks (Fig. 1c). This is not surprising, since $\mathrm{K}$ deficiency is known to impair the synthesis of the important chloroplast protein ribulose bisphosphate carboxylase (Marschner, 1986). An increase in size of the adaxial fibers in these areas was observed (Table 1). In the late stages of $\mathrm{K}$ deficiency (marginal necrosis), complete collapse of the mesophyll and loss of the palisade layer was associated with the necrotic regions of the lamina (Fig. id). Less affected regions of the lamina still exhibited high chloroplast frequency relative to tissue near necrotic areas (Table 1). This pattern suggests that the effects of $\mathrm{K}$ deficiency are not experienced evenly throughout any one particular leaflet, and that levels of $\mathrm{K}$ within the leaf tissue may vary from region to region.

In Mn-deficient leaves, there were fewer chloroplasts, but differentially, as in K-deficient tissue (Table 1). A very striking anatomical feature of Mn deficiency was the marked increase in frequency and diameter of the adaxial fibers underlying the hypodermal layer, a characteristic evenly distributed throughout the affected leaf (Fig. 2 a, b; Table 1).

Iron-deficient leaves (Fig. 2 c, d) showed extreme and uniform reduction in chloroplast frequency, even in the early stages (Fig. 2c, Table 1). This result contrasts with data on sugar beet that showed no decrease in chloroplast frequency with increasing $\mathrm{Fe}$ deficiency (Teny, 1980). As in Mn-deficient leaves, adaxial fibers increased in diameter and number. In more severely Fe-deficient leaves (Fig. $2 \mathrm{~d}$ ), overall mesophyll disintegration was evident in necrotic regions.

The anatomical expression of deficiency symptoms of $\mathrm{K}, \mathrm{Mn}$, and $\mathrm{Fe}$ in queen palm are sufficiently different to allow a more accurate diagnosis than reliance on macromorphological symptoms alone. Reduction in chloroplast frequency occurs in all three deficiencies, but only at uniform levels across $\mathrm{Fe}$-deficient leaves. In $\mathrm{K}$ - and Mn-deficient 
leaves, chloroplast frequency is lowest in the mesophyll cells located near or underlying parts of the leaf exhibiting gross deficiency symptomology. Increases in the diameter (all three deficiencies) and frequency ( $\mathrm{Mn}$ and $\mathrm{Fe}$ ) of adaxial fibers are two of the more striking shared anatomical characteristics (Table 1), although the reasons for these effects remain unknown. Although the physiological development of fibers is not wellunderstood, physical stress is known to foster fiber development (Cutter, 1969; Haberlandt, 1914). The stresses of nutritional deficiency. may have direct effects on endogenous hormone levels, which in turn influence fiber development. Further study of these anatomical changes in association with physiological and ultrastructural investigations may provide insight into which specific organelles are affected by nutrient deficiencies, and may help define tire roles of particular elements in palm physiology.

\section{Literature Cited}

Broeshart, H., J.D. Ferwerda, and W.G. Kovachich. 1957. Mineral deficiency symptoms of the oil palm. Plant \& Soil 8:289-300.

Broschat, T.K. 1984. Nutrient deficiency symptoms in five species of palms grown as foliage plants. Principes 28:6-14.

Broschat, T.K. 1990. Potassium deficiency of palms in south Florida. Principes 34: 151-155.

Broschat, T.K. and H. Donselman. 1985. Causes of palm nutritional disorders. Proc. Fla. State Hort. Soc. 98:101-102.

Bull, R.A. 1961a. Studies on the deficiency diseases of the oil palm. 2. Macronutrient deficiency symptoms in oil palm seedlings grown in sand culture. J. West Afr. Inst. Oil Palm Res. 3:254-264.

Bull, R.A. 1961b. Studies on the deficiency diseases of the oil palm. 3. Micronutrient deficiency symptoms in oil palm seedlings grown in sand culture. J. West Afr. Inst. Oil Palm Res. 3:265-272.

Bussler, W. 1981. Microscopical possibilities for the diagnosis of trace clement stress in plants. J. Plant Nutr. 3:115-128.

Chase, A.R. and T.K. Broscbat (eds.). 1991. Diseases and disorders of palms. Amer. Phytopathol. Soc. Press, St. Paul, Minn. (In press.)

Cutter, E.G. 1969. Plant anatomy: Experiment and interpretation, Part 1, Cells and tissues. Addison-Wesley, Reading, Mass.

Dickey, R.D. 1977. "Nutritional deficiencies of woody ornamental plants used in Florida landscapes. Fla. Agr. Expt. Sta. Bul. 791.

Haberlandt, G. 1914. Physiological plant anatomy. Macmillan, London.

Haschke, H.P. and K. Lüttge. 1975. Interactions between IAA, potassium, and malate accumulation and growth in Avena coeoptile segments. Z. Pflanzenphysiol. 76:450-455.

Manciot, E., M. Ollagnier, and R. Ochs. 1979. Mineral nutrition and fertilization of the coconut around the world. Oleagineaux 34:511-515, 576-580.

Manciot, E., M. Ollagnier, and R. Ochs. 1980. Mineral nutrition and fertilization of the coconut around the world. Oleagineaux 35:23-27.

Marschner, H. 1986. Mineral nutrition in higher plants. Academic, London.

McConnell, D. and B.E. Struckmeyer. 1972. Effect of Alar on boron-deficient Tagetes erects L. Bot. Gaz. 133:135-141.

Sass, J.E. 1958. Botanical microtechnique. Iowa State Univ. Press, Ames.
Singh, S. and C.P. Sharma. 1988. Potassium nutrition of cauliflower. J. Hort. Sci. 63:629-633.

Struckmeyer, B.E. 1960. The effect of inadequate supplies of some nutrient elements on foliar symptoms and leaf anatomy of poinsettia ( $E u$ phorbia pulcherrima Wind.). Proc. Amer. Soc. Hort. Sci. 75:739-747.

Struckmeyer, B.E. 1968. The effects of inadequate supplies of magnesium, calcium and bo- ron on foliar symptoms and leaf anatomy of geranium. Phyton 25:143-150.

Terry, N. 1980. Limiting factors in photosynthesis. I. Use of iron stress to control photochemical capacity in vivo. Plant Physiol. 65:114120.

Tomlinson, P.B. 1961. Anatomy of the monocotyledons (C.R. Metcalfe, cd.). II. Palmae. Clarendon Press, Oxford. 